\title{
EFFECT OF SOME PLANT OILS TREATMENT ON STORAGE EFFICACY OF WHEAT GRAINS
}

Attia, A.N. ${ }^{1}$; M.A. Badawi ${ }^{1}$; S.A. El-Moursy ${ }^{1}$ and A.A. Mohammed ${ }^{2}$

1- Agronomy Department, Faculty of Agriculture, Mansoura University, Egypt.

2- State Company for Grain Broad, Ministry of Trade, Iraq.

\section{ABSTRACT}

A laboratory experiment was carried out under the laboratory conditions of the Experimental Station of Agronomy Department, Faculty of Agriculture, Mansoura University, Egypt, from $15^{\text {th }}$ May to $15^{\text {th }}$ November, 2013. The purpose of the experiment was to assess the effect of some plant oils treatment (neem, coriander and mustard) on storage efficacy of wheat grains under the environmental conditions of Dakahlia Governorate, Egypt, during different storage periods (0,3 and 6 months after harvesting). The most important results obtained from this investigation can be summarized as follows:

- Storage periods of wheat grains had a significant effect on storage efficacy traits. Increasing storage periods of wheat grains from 3 to 6 months significantly increased storage efficacy traits over all studied grain treatments.

- Treating wheat grains with some plant oils i.e. neem oil at the rates of $7.5,15.0$ and $22.5 \%$, coriander and mustard oils at the rates of $5.0,10.0$ and $15.0 \%$ had a significant effect on storage efficacy traits as compared with both control treatments.

It can be recommended treating grains of wheat (Gemmiza 10) with some plant oils (neem oil at the rates of 15.0 and $22.5 \%$ and mustard oil at the rates of 10.0 and $15.0 \%$ ) as an alternative way of use chemicals insecticides to increase storage efficacy and reduce environmental pollution and preservation of human health under the environmental conditions of Dakahlia Governorate, Egypt.

Keywords: Wheat, Storage efficacy, Plant oils, Neem oil, Mustard oil, Coriander oil.

\section{INTRODUCTION}

Wheat (Triticum aestivum L.) is one of the important cereal crop which ranks first among world food crops (Jagshoran et al., 2004). Wheat is the stable food crop in the urban and rural areas; moreover it is used widely in blending with maize flour areas to make bread, macaroni, biscuit and sweets. It is also worth mentioning that wheat straw is a source of fodder for animals.

The average food grains loss in storage condition due to biotic and abiotic factors accounts for $10 \%$ per year, out of which insects are contributing about 2.5 to 5.0 per cent (Girish et al., 1985). Also, damage to stored grains and their products by insects may amount to $5-10 \%$ in the temperate countries to $20-30 \%$ in the tropical zone (Nakakita, 1998). Stored wheat is vulnerable towards attack of insects and a possible infestation can deteriorate the quality as well as the quantity resulting in significant decrease in volume, substantial weight loss and reasonable germination damage (Phillips and Throne, 2010). Due to insect attack, there occurs a considerable increase in humidity and temperature which in turn supports the development of fungus and partial germination of grains (Padin et al., 2013). 
Control of stored product insects relies heavily on the use of synthetic insecticides and fumigants (Rajendran, 1989), which has led to problems such as environmental disturbances, increasing costs of application, pest resurgence, pest resistance to pesticides and lethal effects on non-target organisms (Hashim and Davi, 2003), toxic residues in food grains in addition to direct toxicity to users (Isman, 2006). Due to environmental concerns and human health hazards, several chemical insecticides have either been banned or restricted for use (Tapandjou et al., 2002). Further, due to the problem of resistance to insecticides, there is an urgent need for safer alternatives to conventional chemical insecticides particularly from natural sources, for the protection of grain against insect infestation. In view of all the aspects in grain protection and these problems have highlighted the urgent need to develop newer ecofriendly safer and effective stored-product insecticide such as natural products (plant-derived materials and vegetable oils).

Natural products are an excellent alternative to synthetic pesticides as a means to reduce negative impacts to human health and the environment. The move toward green chemistry processes and the continuing need for developing new crop protection tools with novel modes of action makes discovery and commercialization of natural products such as plant-derived materials and plant essential oils.

Plant-derived materials are more readily biodegradable. Some are less toxic to mammals, may be more selective in action, and may retard the development of resistance. Their main advantage is that they may be easily and cheaply produced by farmers and small-scale industries as crude, or partially purified extracts.

Essential oils are defined as any volatile oil (s) that have strong aromatic components and that give distinctive odour, flavour or scent to a plant. These are the by-products of plant metabolism and are commonly referred to as volatile plant secondary metabolites. Essential oils are found in glandular hairs or secretory cavities of plant-cell wall and are present as droplets of fluid in the leaves, stems, bark, flowers, roots and/or fruits in different plants. The aromatic characteristics of essential oils provide various functions for the plants including (i) attracting or repelling insects, (ii) protecting themselves from heat or cold; and (iii) utilizing chemical constituents in the oil as defense materials (Bakkali et al., 2008).

Azadirachta indica A. Juss (Meliaceae) is a tree, commonly called neem. It has many useful compounds, including azadirachtin and tetranotriterpenoid limonoid, the active ingredient in many neem-based insecticides (Mordue and Blackwell, 1993). All parts of neem especially seed oil possessed antifeedant, repellant, growth disrupting and larvicidal properties against a large number of pests (Mathur, 2013). Moreover, neem derivatives are generally not hazardous to agro-ecosystem, as well as insect resistance is not developed like synthetic insecticides. Various researchers have worked on the effect of neem seed oil on stored grains, among them, Hou et al. (2004) reported that neem prevented the insects piercing and entering into it. Moreover neem was repellent enough to reduce insect immigration into packages but further work is needed to determine if it has 
commercial potential. Anwar et al. (2005) showed that the neem oil was known as insect repellent. They added that neem oil at the rate of $10 \%$ reduced the insect penetration more than those of $5 \%$ significantly, but it was non-significantly different from that of $15 \%$ and $20 \%$. Islam and Talukder (2005) stated that Azadiraechtin, the active principle from the plant Azadiraechta indica (neem), is an antifeedant and insect growth regulator but lacks contact toxicity. Rahman and Talukder (2006) found that plant oils were effective in checking insect infestation. Mossini et al. (2009) reported that oil neem extracts exhibited significant reduction of growth and sporulation of the fungi. Kumawat and Bhanwar (2013) found that the maximum protection of insects was obtained by neem oil, where no grain damage was recorded by neem oil treated grains and no adverse effect of plant oils was observed on seed viability for up to 270 days of treatment. Badawi et al. (2014) stated that significant differences among wheat seed treatments on insect infestation percentage, seed dry weight loss and fungi infestation percentage were detected.

Coriander essential oil is extracted from the seeds of coriander with the help of steam distillation. The scientific name of coriander is Coriandrum sativum. Coriander essential oil consists of compounds like Borneol, Cineole, Cymene, Dipentene, Linalool, Phellandrene, Pinene, Terpineol and Terpinolene, and these are the causes behind its medicinal properties. Moreover, the essential oil of Coriandrum sativum exhibited volatile toxicity to stored product insects (Islam et al., 2009). Islam et al. (2009) investigated the biological activity of essential oil extracted from coriander, Coriandrum sativum L. against eggs, larvae and adults of Tribolium castaneum. They indicated that the oil had fumigant activity against eggs and the toxicity progressively increased with increased exposure times and concentrations.

Mustard oil is considered healthy as it is devoid of trans-fats, is low in saturated fats and has a high content of mono-unsaturated fats and polyunsaturated fatty acids such as omega-3. Thus, it offers an array of health benefits. Mustard oil contains a substance called glucosinolate which is known for its anti-carcinogenic properties and prevents the formation of cancerous tumors. Mustard oil is commonly used as cooking oil and small quantity used for seed treatment, which have no adverse effect on human body when treated grains. Main toxic action of the mustard oil is against egg and early stage larvae. Mustard oil also causes some mortality in adults up to one week of application. Fekadu et al. (2012) indicated that mustard oil was effective in killing the weevil and preventing damage to maize grains. Tiwari (2013) concluded that the indigenous bio products were highly effective for the management of Sitophilus oryzae as a seed protectants.

Therefore, this investigation was established to study the effect of some plant oils treatment on storage efficacy of wheat grains under the environmental conditions of Dakahlia Governorate, Egypt.

\section{MATERIALS AND METHODS}

A laboratory experiment was carried out under the laboratory conditions of the Experimental Station of Agronomy Department, Faculty of 
Agriculture, Mansoura University, Egypt, from $15^{\text {th }}$ May to $15^{\text {th }}$ November, 2013. The purpose of the experiment was to assess the effect of some plant oils treatment on storage efficacy and chemical constituents of wheat grains under the environmental conditions of Dakahlia Governorate, Egypt, during different storage periods ( 0,3 and 6 months after harvesting).

The experiment was arranged in randomized complete block design (RCBD) with four replications. The studied treatments were as follows:

1. Control treatment 1 (storing wheat grains in plastic sacks without any treatment)

2. Control treatment 2 (storing wheat grains in metal containers without any treatment with sealing).

3. Treating wheat grains with neem oil at the rate of $7.5 \%$.

4. Treating wheat grains with neem oil at the rate of $15.0 \%$.

5. Treating wheat grains with neem oil at the rate of $22.5 \%$.

6. Treating wheat grains with coriander oil at the rate of $5 \%$.

7. Treating wheat grains with coriander oil at the rate of $10 \%$.

8. Treating wheat grains with coriander oil at the rate of $15 \%$.

9. Treating wheat grains with mustard oil at the rate of $5 \%$.

10. Treating wheat grains with mustard oil at the rate of $10 \%$.

11. Treating wheat grains with mustard oil at the rate of $15 \%$.

In all studied treatments, $10 \mathrm{~kg}$ of wheat grains were stored. In case of treating with plant oils (treatments from 3 to 11), wheat grains were stored in metal containers with sealing. Storage wheat in metal containers with sealing model was performed as simulation the storage in metal silos as a modern model of storage.

The studied wheat grains were obtained directly after harvesting from the Agricultural Research Station Farm in Tag AL-Ezz, Dakahlia Governorate, Agricultural Research Center, Egypt of Gemmiza 10 cultivar.

The plant oils under study (neem, coriander and mustard) were produced by T. Stanes \& Company Limited, India and obtained from Gaara Establishment for Import and Export Co.

The studied plant oils (neem, coriander and mustard) were dissolved with acetone firstly, and then diluted with water to the studied rates of each plant oil. Wheat grains were sprayed and well mixed with plant oils with various rates, and then beginning storage.

\section{Studied characters:}

\section{- Insect infestation percentage.}

After each storage period ( 3 and 6 months from harvesting), four replicates 100 grains from each treatment were manually picked from each metal container from different depth randomly for inspection. Grains which having holes or infestation were collected also, the grain which showed sings of insect damage were considered as infested. The infestation level was expressed as number and percentage damage grains according to formula of Jood et al. (1996).

$$
\text { Damage grains percent }=\frac{\text { Number of insect damage }}{\text { Number of total grains inspected }} \times 100
$$


- Grains weight loss percentage:

After 3 and 6 months, the dry mass (weight) losses caused by insect infestation were calculated as follows according to Dick (1987).

$$
\text { Dry mass (weight) loss } \%=\frac{(\mathrm{UNd})-(\mathrm{DNu})}{U(\mathrm{Nd}+\mathrm{Nu})} \times 100
$$

Where: $\mathrm{Nu}=$ Number of undamaged grains.

$\mathrm{Nd}=$ Number of damaged grains.

$\mathrm{U}=$ Weight of undamaged grains.

$\mathrm{D}=$ Weight of damage grains .

All obtained data were statistically analyzed according to the technique of analysis of variance (ANOVA) for the randomized complete block design (RCBD) for each storage period, then combined analysis was done between storage periods ( 3 and 6 months) as published by Gomez and Gomez (1984) by using means of "MSTAT-C" computer software package. Means of grains treatments were compared using Duncan's multiple range tests at $5 \%$ level of probability as described by Duncan (1955). New least significant of difference (NLSD) method was also used to test the differences between treatment means at $5 \%$ level of probability as described by Waller and Duncan (1969).

\section{RESULTS AND DISCUSSION}

Storage periods of wheat grains ( 3 and 6 months after harvesting) had a significant effect on storage efficacy traits (number of infected wheat grains, damage grains percentage and grains weight loss percentage) as shown in Table 1. Increasing storage periods of wheat grains from 3 to 6 months significantly increased number of infected wheat grains, damage grains percentage, grains weight loss percentage, over all studied grain treatments.

The statistical analysis of obtained results showed that treating wheat grains with some plant oils i.e. neem oil at the rates of $7.5,15.0$ and $22.5 \%$, coriander and mustard oils at the rates of $5.0,10.0$ and $15.0 \%$ had a significant effect on storage efficacy traits (number of infected wheat grains, damage grains percentage and grains weight loss percentage) as compared with both control treatments i.e. storing wheat grains in plastic sacks without any treatment or storing wheat grains in metal containers without any treatment with sealing after 3 and 6 months of beginning storage as well as combined over storage periods.

\section{- Effect of treating wheat grains with neem oil:}

From obtained results, treating wheat grains with neem oil at the rates of $7.5,15.0$ and $22.5 \%$ after 3 months of storage gave the best results of storage efficacy traits (number of infected wheat grains, damage grains percentage and grains weight loss percentage) without significant differences among them as shown in Tables 1,2 and graphically illustrated in Fig. 1, Fig. 2 and Fig. 3. 
Table 1: Number of infected wheat grains, damage grains and grains weight loss percentages as affected by treating grains with some plant oils after 3 and 6 months of storage.

\begin{tabular}{|c|c|c|c|c|c|c|}
\hline \multirow[b]{2}{*}{ Treatments } & \multicolumn{2}{|c|}{$\begin{array}{c}\text { Number of } \\
\text { infected grains }\end{array}$} & \multicolumn{2}{|c|}{$\begin{array}{c}\text { Damage grains } \\
(\%)\end{array}$} & \multicolumn{2}{|c|}{$\begin{array}{c}\text { Grains weight loss } \\
(\%)\end{array}$} \\
\hline & $\begin{array}{l}\text { After } 3 \\
\text { months }\end{array}$ & $\begin{array}{c}\text { After } 6 \\
\text { months }\end{array}$ & $\begin{array}{c}\text { After } 3 \\
\text { months }\end{array}$ & $\begin{array}{l}\text { After } 6 \\
\text { months }\end{array}$ & $\begin{array}{c}\text { After } 3 \\
\text { months }\end{array}$ & $\begin{array}{c}\text { After } 6 \\
\text { months }\end{array}$ \\
\hline Control 1 & $4.62 \mathrm{a}$ & $8.56 a$ & $3.57 a$ & $6.78 a$ & $10.01 a$ & $35.08 a$ \\
\hline Control 2 & $3.31 \mathrm{~b}$ & $5.00 \mathrm{~b}$ & $2.52 b$ & $3.90 \mathrm{a}$ & $5.09 \mathrm{~b}$ & $13.38 b$ \\
\hline Neem oil at the rate of $7.5 \%$ & $0.00 \mathrm{e}$ & $2.50 \mathrm{de}$ & $0.00 \mathrm{e}$ & $1.96 \mathrm{~d}$ & $0.00 \mathrm{e}$ & $3.25 \mathrm{cde}$ \\
\hline Neem oil at the rate of $15 \%$ & $0.00 \mathrm{e}$ & 2.06def & $0.00 \mathrm{e}$ & $1.62 d$ & $0.00 \mathrm{e}$ & $2.19 \mathrm{de}$ \\
\hline Neem oil at the rate of $22.5 \%$ & $0.00 \mathrm{e}$ & $1.81 f$ & $0.00 \mathrm{e}$ & $1.47 d$ & $0.00 \mathrm{e}$ & $1.93 \mathrm{de}$ \\
\hline Foriander oil at the rate of $5 \%$ & $2.06 \mathrm{c}$ & $3.25 \mathrm{c}$ & $1.63 \mathrm{c}$ & $2.58 \mathrm{c}$ & $2.56 \mathrm{~cd}$ & $5.98 \mathrm{c}$ \\
\hline oriander oil at the rate of $10 \%$ & $1.43 d$ & $2.56 \mathrm{~d}$ & $1.11 \mathrm{~d}$ & $2.03 d$ & $1.22 \mathrm{de}$ & $3.70 \mathrm{~cd}$ \\
\hline oriander oil at the rate of $15 \%$ & $1.37 d$ & $1.87 \mathrm{ef}$ & $1.06 \mathrm{~d}$ & $1.51 d$ & $1.07 \mathrm{de}$ & $1.89 \mathrm{de}$ \\
\hline Mustard oil at the rate of $5 \%$ & $2.56 \mathrm{c}$ & $3.50 \mathrm{c}$ & $2.06 \mathrm{bc}$ & $2.78 \mathrm{c}$ & $3.44 \mathrm{c}$ & $6.45 c$ \\
\hline Mustard oil at the rate of $10 \%$ & $0.00 \mathrm{e}$ & $0.00 \mathrm{~g}$ & $0.00 \mathrm{e}$ & $0.00 \mathrm{e}$ & $0.00 \mathrm{e}$ & $0.00 \mathrm{e}$ \\
\hline Mustard oil at the rate of $15 \%$ & $0.00 \mathrm{e}$ & $0.00 \mathrm{~g}$ & $0.00 \mathrm{e}$ & $0.00 \mathrm{e}$ & $0.00 \mathrm{e}$ & $0.00 \mathrm{e}$ \\
\hline F. test & * & $*$ & * & 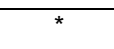 & * & * \\
\hline NLSD at $5 \%$ & 0.29 & 0.32 & 0.24 & 0.25 & 1.58 & 1.58 \\
\hline
\end{tabular}

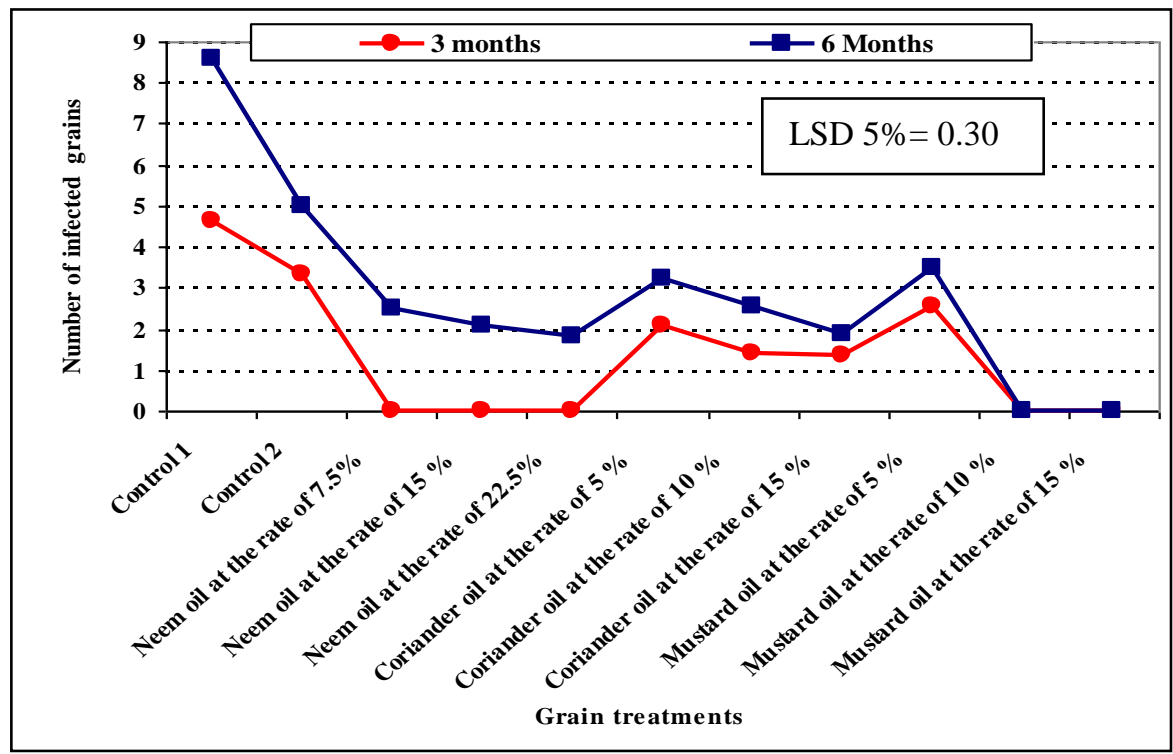

Fig. 1: Number of infected wheat grains as affected by the interaction between storage periods and treating grains with some plant oils. 


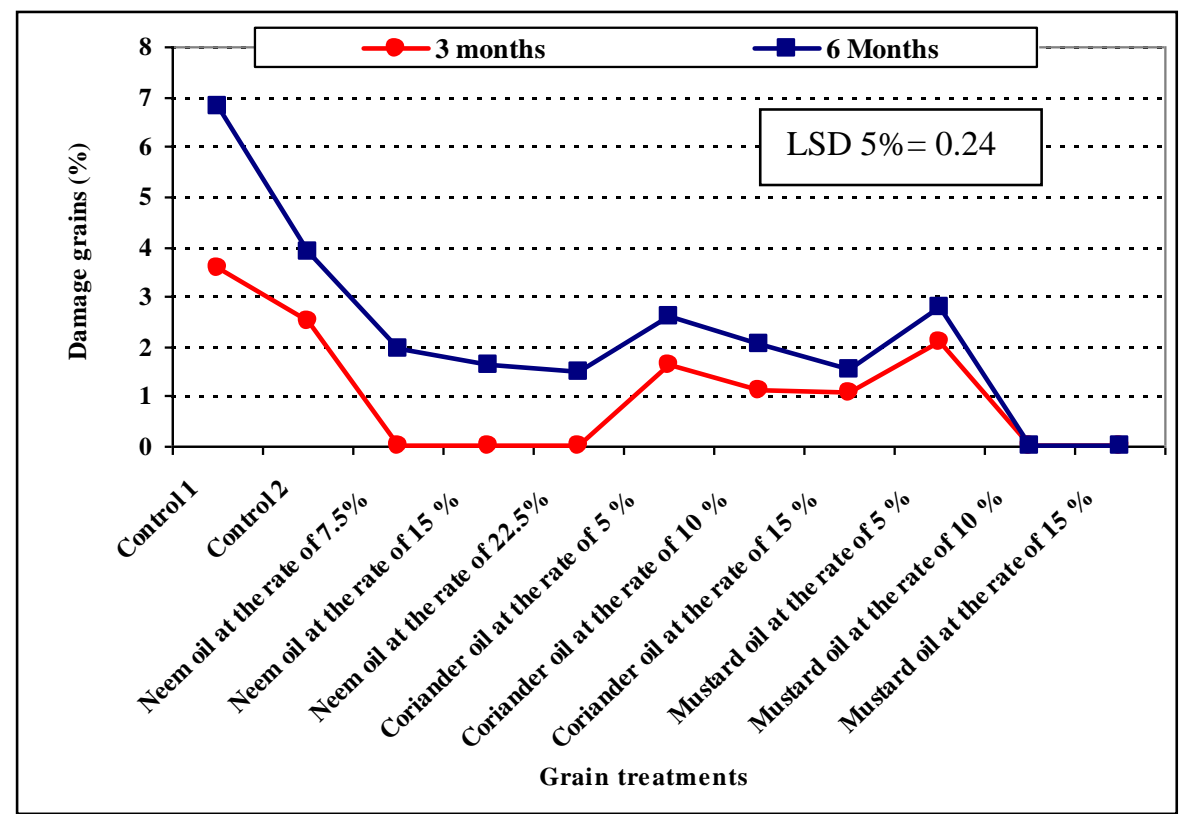

Fig. 2: Damage grains percentage as affected by the interaction between storage periods and treating grains with some plant oils.

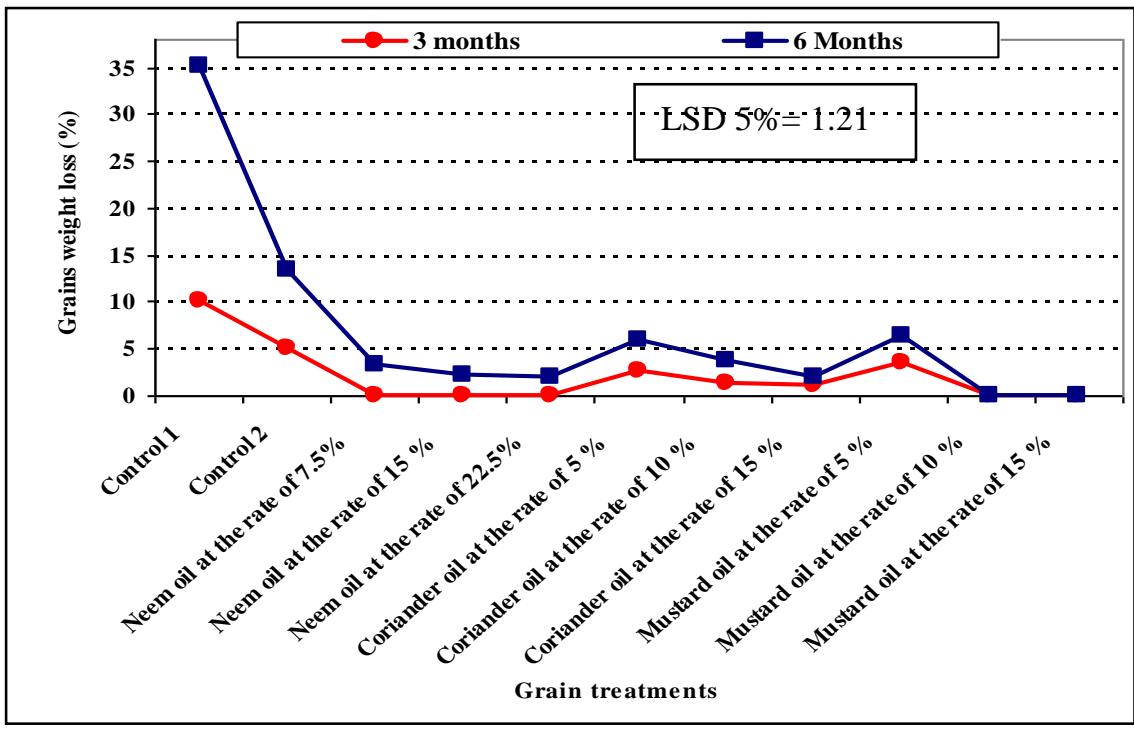

Fig. 3: Grains weight loss percentage as affected by the interaction between storage periods and treating grains with some plant oils. 
The statistical analysis of obtained results showed that treating grains with neem oil at the rates of $7.5,15.0$ and $22.5 \%$ resulted in the best results of storage efficacy traits (number of infected wheat grains, damage grains percentage and grains weight loss percentage) after 6 months of storage without significant differences among them.

The reason that caused prevent or reduce wheat grains to infect (number of infected wheat grains, damage grains percentage and grains weight loss percentage) with insects due to treatment with neem oil at the rates of $7.5,15.0$ and $22.5 \%$ before initiation of storage may be due to neem seed oil is considered as antifeedant, repellant, growth disrupting and larvicidal properties against a large number of pests (Mathur, 2013). Thus, extract of neem especially seed oil was the most effective botanical insecticide (Zaidi et al., 2003).

\section{- Effect of treating wheat grains with mustard oil:}

From obtained results, treating wheat grains with mustard oil at the rates of $5.0,10.0$ and $15.0 \%$ had the same effectiveness of neem oil on the wheat grains after 3 months of storage, which produced the highest values of storage efficacy traits (number of infected wheat grains, damage grains percentage and grains weight loss percentage) as shown in Tablef 1,2 and graphically illustrated in Fig. 1, Fig. 2 and Fig. 3.

The statistical analysis of obtained results showed that the best obtained result of storage efficacy traits (number of infected wheat grains, damage grains percentage and grains weight loss percentage) were recorded from treating grains with mustard oil at the rates of $15.0,10.0$ and $5.0 \%$.

Avoiding or slightest of (number of infected wheat grains, damage grains percentage and grains weight loss percentage) as a result of treating wheat grains with mustard oil particularly at high rates (10 and 15\%) may be recognized to formation of glucosinolates as secondary metabolites that help plants defend themselves against phytophagous insects, fungi and other pests (Dhingra et al., 2004). The glucosinolates are enzymatically hydrolyzed to the sugar moiety and isothiocyanates. Allyl isothiocyanate (AITC) is the most toxic compound formed from allyl glucosinolate hydrolysis (Mayton et al., 1996), and possibly the most important for biofumigation (Noble et al., 2002).

\section{- Effect of treating wheat grains with coriander oil:}

Treating wheat grains with coriander oil at the rates of 15.0, 10.0 and $5.0 \%$ ranked after neem and mustard oils with concern storage efficacy traits (number of infected wheat grains, damage grains percentage and grains weight loss percentage) after 3 months of storage. As shown in Tables 1,2 and graphically illustrated in Fig. 1, Fig. 2 and Fig. 3.

After 6 months of storage, the statistical analysis of obtained results showed that treating grains with coriander oil at the rates of 15.0, 10.0 and $5.0 \%$ recorded the second best results of storage efficacy traits (number of infected wheat grains, damage grains percentage and grains weight loss percentage).

Treating wheat grains with coriander oil at different rates $(5,10$ and $15 \%$ ) associated with slight effect on grains on both of (number of infected wheat grains, damage grains percentage and grains weight loss percentage) 
as compared treating with neem or mustard oils after 3 and 6 month of storage as well combined over storage periods, these results may be due to the essential oil of coriander exhibited good fumigant, repellent and volatile toxicity against larvae and adult insects (Pascual-Villalobos and BallestaAcosta, 2003 ; Farhana et al., 2006 ; Islam et al., 2009 and Rani, 2012).

\section{- Effect of control treatments:}

Studied control treatments (storing wheat grains in plastic sacks without any treatment and storing wheat grains in metal containers without any treatment with sealing), respectively recorded the lowest values of storage efficacy traits (number of infected wheat grains, damage grains percentage and grains weight loss percentage) after 3 months of storage. As shown in Tables 1,2 and graphically illustrated in Fig. 1, Fig. 2 and Fig. 3.

After 6 months of storage, the statistical analysis of obtained results showed that storage wheat grains in plastic sacks without any treatment (control treatment 1) and storing wheat grains in metal containers without any treatment with sealing (control treatment 2) recorded the lowest values respectively of storage efficacy traits (number of infected wheat grains, damage grains percentage and grains weight loss percentage).

Increasing grains on both of (number of infected wheat grains, damage grains percentage and grains weight loss percentage) when storing wheat grains in plastic sacks without any treatment (control treatment 1) or storing wheat grains in metal containers without any treatment with sealing (control treatment 2) as compared with treating grains with some plant oils (neem, coriander and mustard) after 3 and 6 month of storage as well combined over storage periods may be owing to appropriate conditions for the growth, establishment, development and spread of insects, and at the same time, absence of factors that limit the growth of insects. These results are in accordance with those stated by Khalequzzaman et al. (2007), Gemechu et al. (2013) and also Badawi et al. (2014) who stated that significant differences among wheat seed treatments on insect infestation number and percentage was detected.

\section{CONCLUSION}

It can be concluded that treating grains of wheat (Gemmiza 10) with some plant oils (neem oil at the rates of 15.0 and $22.5 \%$ and mustard oil at the rates of 10.0 and $15.0 \%$ ) as an alternative way of use chemicals insecticides to increase storage efficacy and reduce environmental pollution and preservation of human health under the environmental conditions of Dakahlia Governorate, Egypt.

\section{REFERENCES}

Anwar, M. ; A. Muhammad ; H. Mansoor and M.A. Faqir (2005). Efficacy of Azadirachta indica oil on bagging material against some insect pests of wheat stored in warehouses at Faisalabad. Pakistan Entomol., 27(1): 89-94. 
Badawi, M.A. ; A.M. Salama ; I.F.A. Mersal and N.E. Attia (2014). Effect of some seed treatments before storage on wheat seed quality. J. Plant Production, Mansoura Univ., 5(4): 545-554.

Bakkali, F. ; S. Averbeck ; D. Averbeck and M. Idaomar (2008). Biological effects of essential oils: A review. J. of Food Chem. and Toxico., 46: 446-475. http://dx.doi.org/10.1016/ j.fct.2007.09.106.

Dhingra, O.D. ; M.L.N.Costa and G.J. Silva Júnior (2004). Potential of allyl isothiocyanate to control Rhizoctonia solani seedling damping off and seedling blight in transplant production. J. Phytopathology, 152: 352357.

Dick, K.M. (1987). Pest management in stored groundnuts. ICRISAT Information Bulletin No. 22, Patancheru, Hyderabad, India.

Duncan, D.B. (1955). Multiple range and multiple F test. Biometrics, 11: 1-42.

Farhana, K. ; H. Islam ; E.H. Emran and N. Islam (2006). Toxicity and repellent activity of three spice materials on Tribolium castaneum $(\mathrm{H})$ adults. J. of Biosci., 14: 127-130.

Fekadu G. ; S. Waktole and D.R. Santiago (2012). Evaluation of plant powders and cooking oils against maize weevil, Sitophilius zeamais M. (Coleoptera: Curcurleonidae) under laboratory conditions. Mol. Entomol., 3:4-14.

Gemechu F. ; D. R. Santiago and W. Sori (2013). Laboratory evaluation of cotton (Gossypium hirsutum) and Ethiopian mustard (Brassica cariata) seed oils as grain protectants against maize weevil, Sitophilus zeamais M. (Coleoptera : Curculionidae). African J. of Agric. Res., 8(32): 43744379.

Girish, G.K. ; R.K. Goyal and K. Krishnamurthy (1985). Steps taken by department of food for minimizing post-harvest losses at farm level. Bull. Grain Tech., 23: 168-181.

Gomez, K.A. and A.A. Gomez (1984). Statistical Procedures for Agricultural Research. $2^{\text {nd }}$ Ed., Jhon Wiley and Sons Inc., New York, pp: 95-109.

Hashim, M.S. and K.S. Davi (2003). Insecticidal action of the polyphenolic rich fractions from the stem bark of Streblus asper on Dysdercus cingulalus. Fitoterapia, 8: 670-676.

Hou, X. ; P. Fields and W. Taylor (2004). The Effect of repellents on penetration into packaging by stored-product insects. J. of Stored Product Res., 40: 47-54.

Islam, M.S ; M.M. Hasan ; W. Xiong ; S.C. Zhang and C.L. Lei (2009). Fumigant and repellent activities of essential oil from Coriandrum sativum (L.) (Apiaceae) against red flour beetle Tribolium castaneum (Herbst) (Coleoptera: Tenebrionidae). J. of Pest Sci.,_82(2): 171-177.

Islam, M.S. and F.A.Talukder (2005). Toxic and residual effects of Azadirachta indica, Tagets erecta and Cynodon dactylon extracts against Tribolium castaneum. J. of Plant Diseases Protection, 12: 594600.

Isman, M.B. (2006). Botanical insecticides, deterrents, and repellents in modern agriculture and an increasingly regulated world. Annual Review of Entomology, 51: 45-66. 
Jagshoran, A. ; R. K. Sharma and S. C. Tripathi (2004). New varieties and production. The Hindu, Survey of Indian Agric., pp: 33-35.

Jood, S. ; A. C. Kapoor and S. Ram (1996). Evaluation of some plant products against Trigoderma granarium Everts in Sorghum and their effects on nutritional composition and oranoleptic characteristics. J. Stored prod. Res., 32 (4): 345-352.

Khalequzzaman, M. ; S.H. A Mahdi and S.H.M. Osman-Goni (2007). Efficacy of edible oils in the control of pulse beetle, Callosobruchus chinensis $\mathrm{L}$. in stored pigeonpea. Univ. J. Zool. Rajshahi Univ., 26: 89-92.

Kumawat, K.C. and L.N. Bhanwar (2013). Effect of plant oils on the infestation of Rhyzopertha Dominica (Fab.) in wheat, Triticum aestivum L.. J. of Plant Protection Res., 53(3): 301-304.

Mathur, S. (2013). Biopesticidal activity of Azadirachta indica A Juss. Res. J. Pharm. Biol. Chem. Sci., 4(2): 1131-1136.

Mayton, H.S. ; C. Olivier ; S.F. Vaughn and R. Loria, (1996). Correlation of fungicidal activity of Brassica species with allyl isothiocyanate production in macerated leaf tissue. J. Phytopathology, 86: 267-271.

Mordue, A.J. and A. Blackwell (1993). Azadirachtin: an update. J. Insect Physiol., 39: 903-924.

Mossini, S.A.G. ; C.C. Arrotéia and C. Kemmelmeier (2009). Effect of neem leaf extract and neem oil on penicillium growth, sporulation, morphology and ochratoxin a production. Toxins, 1: 3-13.

Nakakita, H. (1998). Stored rice and stored product insects. In: Nakakita H. (Ed.). Rice Inspection Technology. Tokyo: A.C.E. Corporation, pp: 4965.

Noble, R.R.P. ; S.G. Harvey and C.E. Sams (2002). Toxicity of Indian Mustard and allyl isothiocyanate to masked chafer beetle larvae. Plant Management Network. URL: http://www. plantmanagementnetwork.org /pub/php/research/chafer/. Retrieved July 2006.

Padin, S.B. ; C. Fuse ; M.I. Urrutia and G.M.D. Bello (2013). Toxicity and repellency of nine medicinal plants against Tribolium castaneum in stored wheat. Bull. of Insecto., 66: 45-49.

Pascual-Villalobos, M.J. and M.C. Ballesta-Acosta (2003). Chemical variation in an Ocimum basilicum germplasm collection and activity of the essential oils on Callosobruchus maculatus. Biochemical Systematics and Ecology, 31: 673-679.

Phillips, T.W. and J.E. Throne (2010). Bio-rational approaches to managing stored product. Ann. Rev. of Entom., 55: 375-397.

Rahman, A. and F.A. Talukder (2006). Bioefficacy of some plant derivatives that protect grain against the pulse beetle (Callosobruchus maculates). J. Insect Sci., 6(3): 1-10.

Rajendran, S. (1989). Fumigant resistance ; problems and its implications in the control of stored product insects in India. Pest. Res. J., 1(2): 111115.

Rani, P.U. (2012). Fumigant and contact toxic potential of essential oils from plant extracts against stored product pests . J. of Biopesticides, 5(2): 120. 
Tapondjou, L.A. ; A. Alder ; H. Bonda and D.A. Fontem (2002). Efficacy of powder and essential oil from Chenopodium ambrosioides leaves as post-harvest grain protectants against six-stored product beetles. J. of Stored Products Res., 38: 395-402.

Tiwari, R. (2013). Efficacy of some indigenous bioproducts against rice weevil, Sitophilus oryzae (Linn.) on wheat. Indian J. of Applied Res., 3(6): 13-15.

Waller, R.A. and D.B. Duncan (1969). A bays rule for the symmetric multiple comparison problem. J. Amer. Assoc., 64: 1484-1503.

Zaidi, S.R. ; G. Jilani ; J. lqbal ; M. Ashfaque and U. Rafique (2003). Settling response of Angumois moth, Sitotroga cerealella (Oliv.) to plant derivatives. Pakistan. Entomol., 25(1): 107-112.

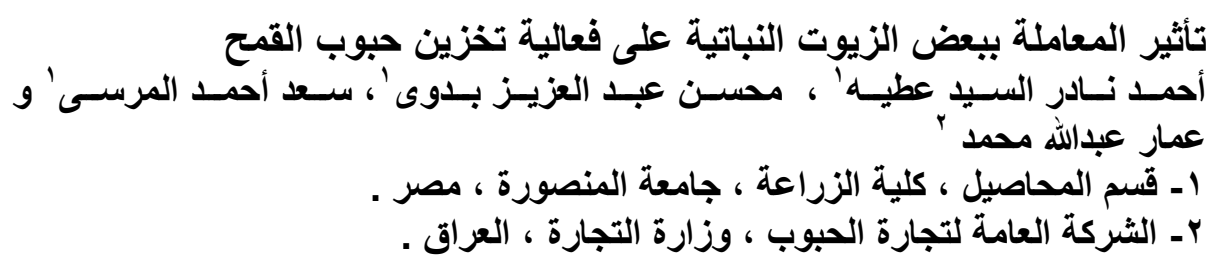

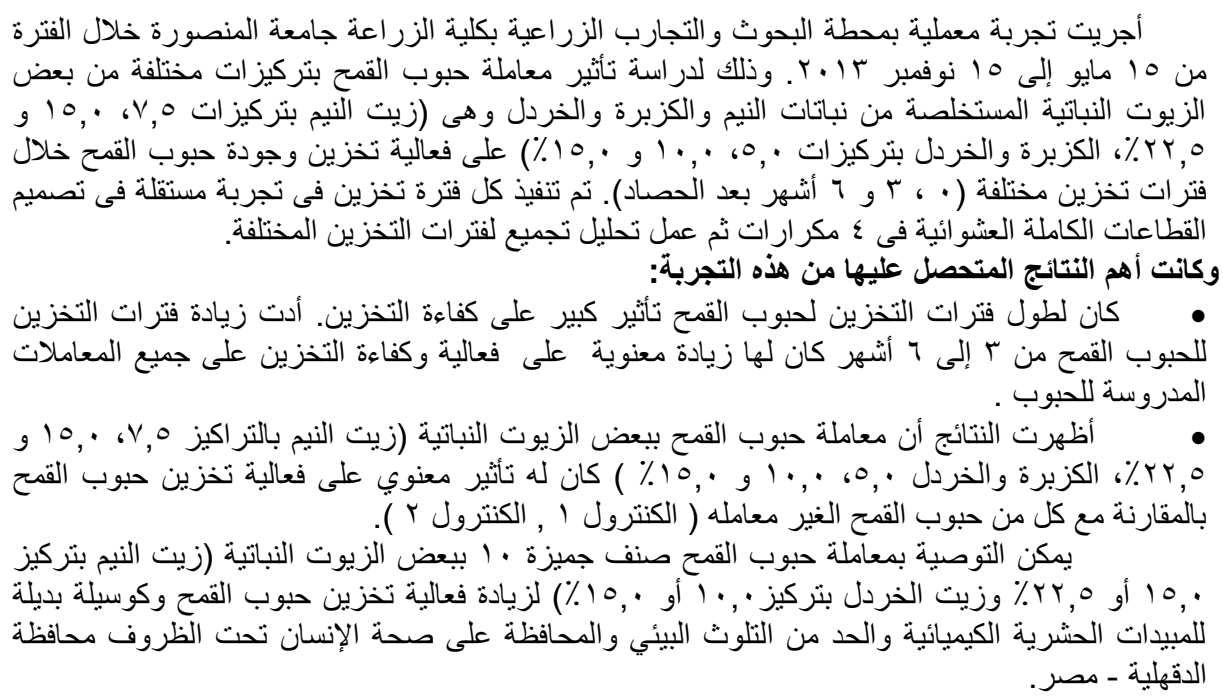

